\title{
CARES: Carbonaceous Aerosol and Radiative Effects Study Operations Plan
}

June 2010

RA Zaveri

Principal Investigator

WJ Shaw

DJ Cziczo 


\section{DISCLAIMER}

This report was prepared as an account of work sponsored by the U.S. Government. Neither the United States nor any agency thereof, nor any of their employees, makes any warranty, express or implied, or assumes any legal liability or responsibility for the accuracy, completeness, or usefulness of any information, apparatus, product, or process disclosed, or represents that its use would not infringe privately owned rights. Reference herein to any specific commercial product, process, or service by trade name, trademark, manufacturer, or otherwise, does not necessarily constitute or imply its endorsement, recommendation, or favoring by the U.S. Government or any agency thereof. The views and opinions of authors expressed herein do not necessarily state or reflect those of the U.S. Government or any agency thereof. 


\title{
CARES: Carbonaceous Aerosol and Radiative Effects Study Operations Plan
}

\author{
RA Zaveri, Pacific Northwest National Laboratory \\ WJ Shaw, Pacific Northwest National Laboratory \\ DJ Cziczo, Pacific Northwest National Laboratory
}

June 2010

Work supported by the U.S. Department of Energy,

Office of Science, Office of Biological and Environmental Research 


\section{Contents}

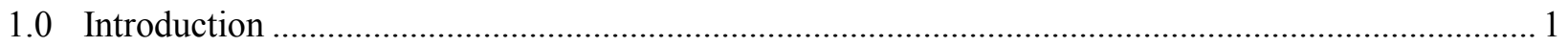

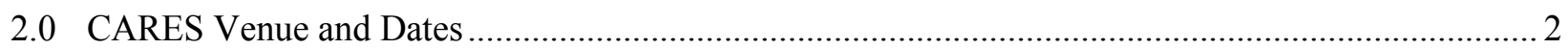

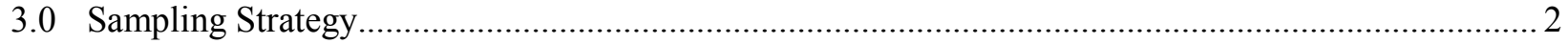

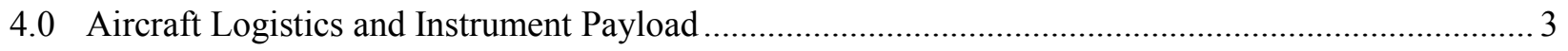

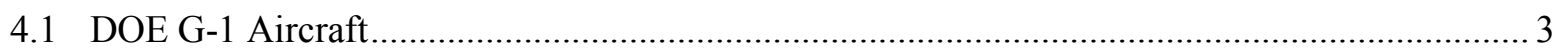

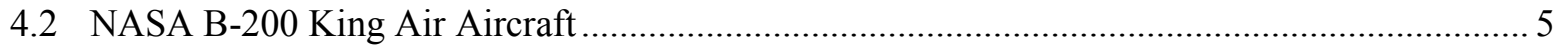

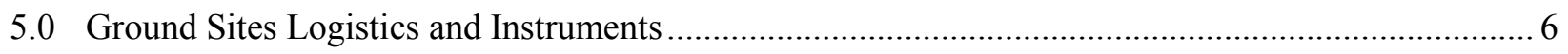

5.1 T0 Site: American River College, Sacramento, California .................................................... 6

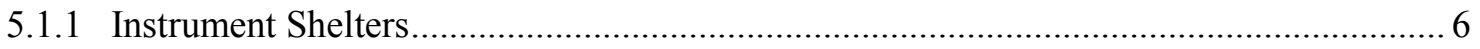

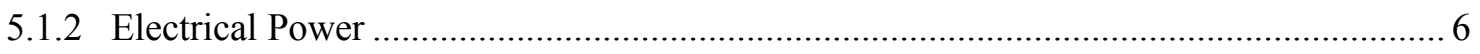

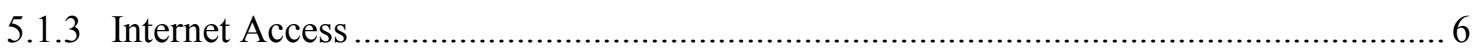

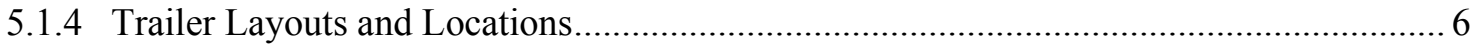

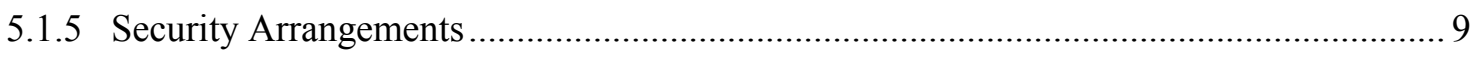

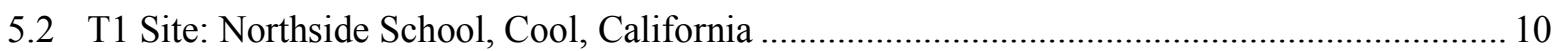

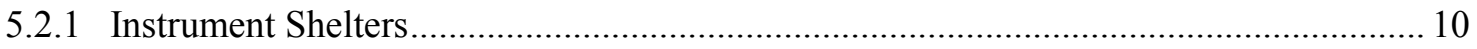

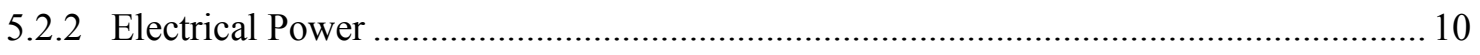

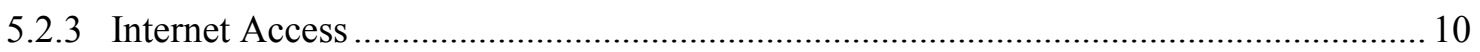

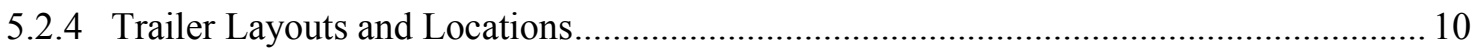

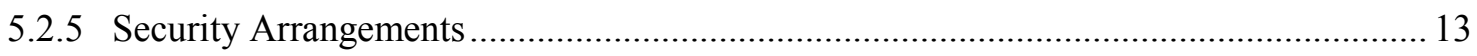

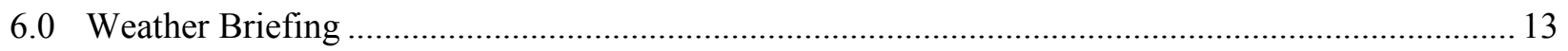

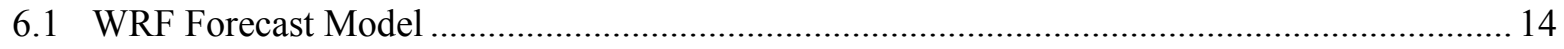

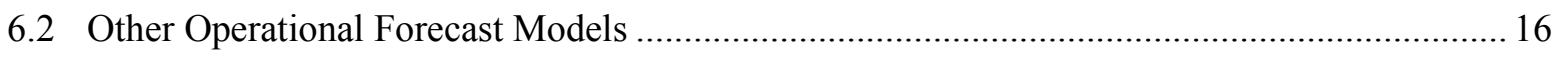

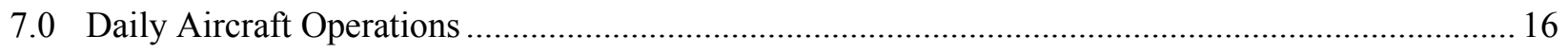

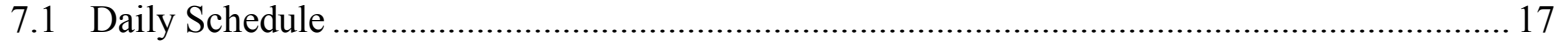

7.1.1 Tentative schedule for the CARES campaign June $2-28^{\text {th }} 2010,4$ weeks ..................... 19

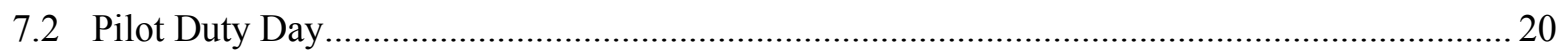

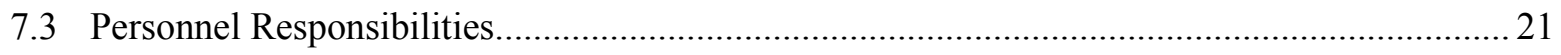

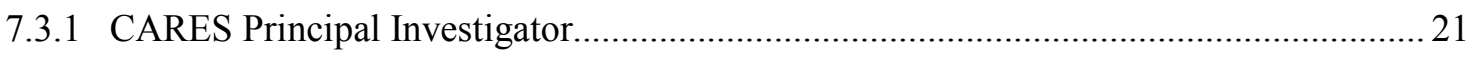

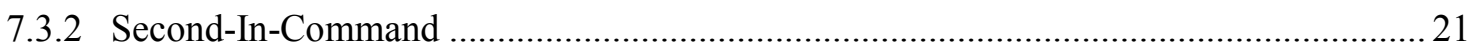

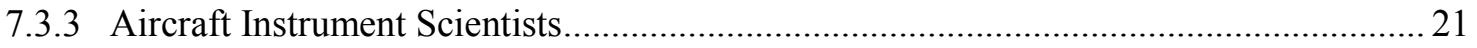

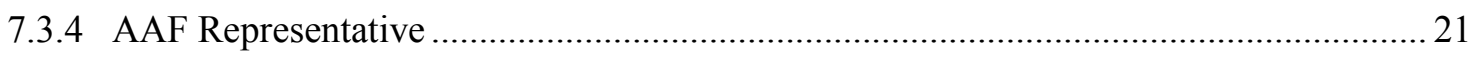

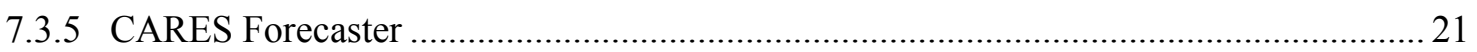

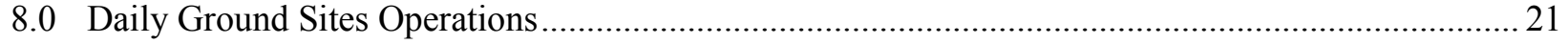

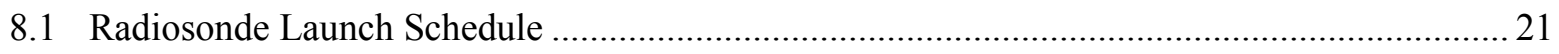

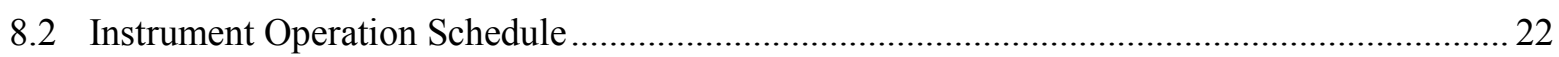




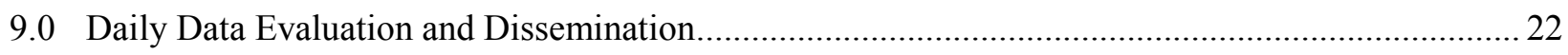

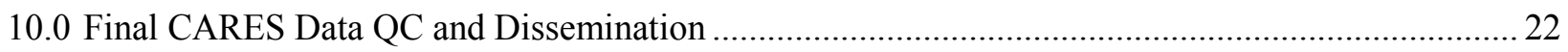

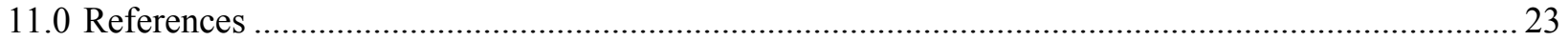

\section{Figures}

1 Locations of the planned ground sites for CARES..................................................................... 3

2 G-1 cabin floor plan for the payload listed in Table 1 ................................................................. 5

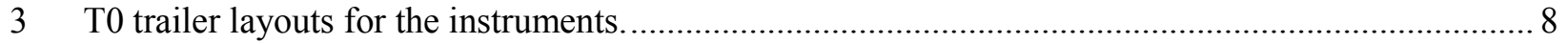

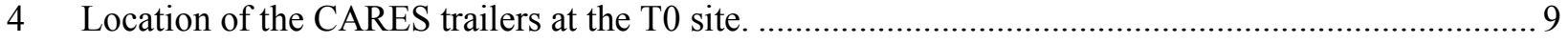

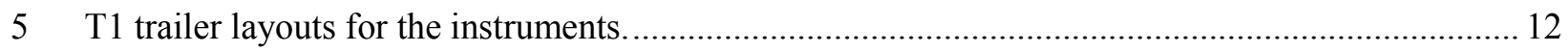

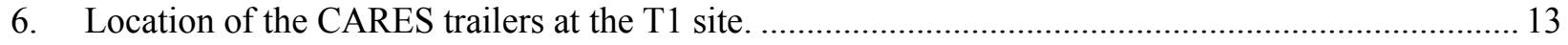

7 Domain of the WRF tracer forecast model using a horizontal grid spacing of $4 \mathrm{~km}$ and $280 \mathrm{x}$

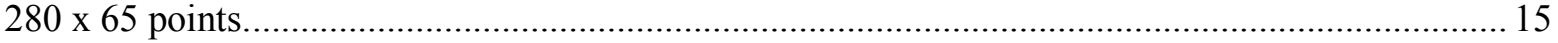

8 Example tracer forecast depicting simulated $\mathrm{CO}$ from all sources and those from local

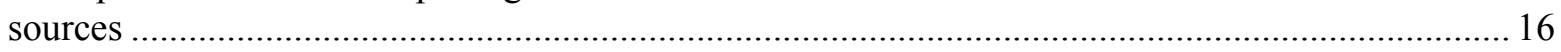

9 Diagram listing the steps needed to generate a forecast from WRF............................................. 16

\section{Tables}

1 List of Planned Measurements and Instruments onboard the DOE G-1 aircraft. .............................. 4

2 List of Planned Measurements and Instruments onboard the NASA B-200 King Air aircraft............ 5

3 List of Planned Measurements and Instruments at T0 .................................................................. 7

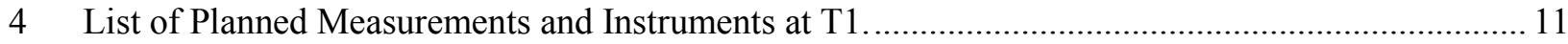

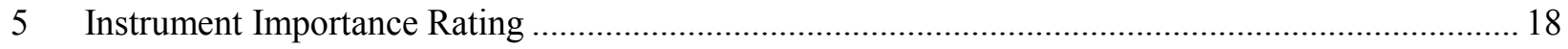

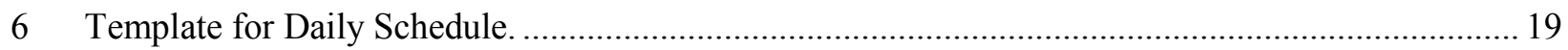

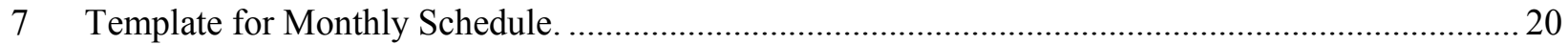




\subsection{Introduction}

One of the goals of the U.S. Department of Energy's (DOE) Atmospheric System Research (ASR) is to develop, evaluate, and improve process modules and parameterizations describing aerosol processes and properties, so that they can be reliably used in regional and global models to assess the direct and indirect aerosol radiative effects on the climate system. Furthermore, particular emphasis is placed on improving the scientific understanding of the role of anthropogenic emissions on aerosol formation and how they interact with natural aerosols and age over a range of meteorological and chemical environments via an integrated approach to field, laboratory, and modeling studies.

Field observations show that tropospheric aerosol particles can be composed of a wide variety of compounds, including sulfate, nitrate, ammonium, sea salt, crustal species from soil dust, and carbonaceous materials (Seinfeld and Pandis 1998). Primary carbonaceous aerosols include black carbon (BC) particles (or light-absorbing carbon) mixed with nominally non-absorbing organic compounds that are directly emitted from fossil fuel combustion, cooking, industrial processes, and biomass burning (agricultural burning and natural wildfires). Secondary carbonaceous aerosols, commonly referred to as secondary organic aerosols (SOA), are formed via homogeneous nucleation, condensation, and heterogeneous reactions of myriad photochemical oxidation products from numerous volatile and semivolatile organic compounds of both anthropogenic and biogenic origins. Analyses of ambient aerosols have shown that carbonaceous compounds constitute between $20 \%$ and $90 \%$ of the dry particle mass (Kanakidou et al. 2005, Zhang et al. 2007).

Although some process-level uncertainties still exist (e.g., new particle formation), the formation, evolution, and properties of the key inorganic components of tropospheric aerosols are now relatively well understood and adequately represented in state-of-the-art aerosol models (e.g., Wexler and Seinfeld 1991, Jacobson 2002, Zhang et al. 2004, Zaveri et al. 2008). On the other hand, large uncertainties still exist in the fundamental understanding of the formation, evolution, and climate-affecting properties of the various carbonaceous components of tropospheric aerosols. Consequently, the available aerosol models do not have reliable treatments for the formation and evolution of carbonaceous aerosol mass, sizedistribution, and mixing state, let alone the related hygroscopic and optical properties.

The CARES field campaign is motivated by the scientific issues described in the CARES Science Plan. The primary objectives of this field campaign are to investigate the evolution and aging of carbonaceous aerosols and their climate-affecting properties in the urban plume of Sacramento, California, a mid-size, mid-latitude city that is located upwind of a biogenic volatile organic compound (VOC) emission region. Our basic observational strategy is to make comprehensive gas, aerosol, and meteorological measurements upwind, within, and downwind of the urban area with the DOE G-1 aircraft and at strategically located ground sites so as to study the evolution of urban aerosols as they age and mix with biogenic SOA precursors. The NASA B-200 aircraft, equipped with the High Spectral Resolution Lidar (HSRL), digital camera, and the Research Scanning Polarimeter (RSP), will be flown in coordination with the G-1 to characterize the vertical and horizontal distribution of aerosols and aerosol optical properties, and to provide the vertical context for the G-1 and ground in situ measurements. 


\subsection{CARES Venue and Dates}

The CARES campaign will be centered on Sacramento, California, from June 2 through 28, 2010. Sacramento is located in California's expansive Central Valley and is the seventh most populous city in California with a 2007 estimated population of 467,343. The four-county Sacramento Metropolitan Area is the largest in the Central Valley, with a population of 2.1 million. While transport processes over the entire Central Valley can be complex (Bao et al. 2008), the transport of the Sacramento urban plume during the summer is controlled by extremely consistent, terrain-driven upslope winds that draw polluted air to the northeast over oak and pine trees in the Blodgett Forest area in the Sierra Nevada by late afternoon. The Sacramento-Blodgett Forest corridor effectively serves as a mesoscale $(\sim 100 \mathrm{~km})$ daytime flow reactor where the daily evolution of the Sacramento urban plume can be characterized as a Lagrangian air parcel transported from the urban core into the sparsely populated Sierra Nevada Mountains (Dillon et al. 2002, Murphy et al. 2007). The Sacramento-Blodgett Forest corridor is therefore ideally suited for deploying multiple ground sites and aircraft sampling within and outside of the urban plume and the biogenic VOC-dominated areas.

Moreover, the Central Valley location of CARES will allow us to take advantage of planned agricultural fires around Sacramento and possibly natural wildfires in the vicinity to study the evolution and properties of biomass burning carbonaceous aerosols.

\subsection{Sampling Strategy}

Figure 1 shows the locations of the two ground sites planned for CARES. The "T0" site is located within the Sacramento urban source area (on the campus of American River College), which is about $14 \mathrm{~km}$ to the northeast of the Sacramento downtown area. The "T1" site is located in the downwind area about $40 \mathrm{~km}$ further to the northeast at the K-8 Northside School in the small town of Cool, California, situated amidst biogenic (forest) emissions. The aged urban plume typically arrives at this location around midafternoon when ozone, and presumably SOA from urban precursors, is at or near its peak concentration. This timing is consistent with the time-scale for rapid SOA growth reported by de Gouw et al. (2008). As mentioned earlier, there are already substantial amounts of trace gas and aerosol data at the Blodgett Forest site, which is located about $20 \mathrm{~km}$ further northeast in the Sierra Mountains. These data show a distinct but rather weak signal of the Sacramento urban plume in the late afternoon, which is another reason why we have proposed to place the T1 site at Cool, closer to Sacramento. The T0 and T1 ground sites will thus characterize the diurnal evolution of meteorological variables, trace gases/aerosol precursors, and aerosol composition and properties in freshly polluted and aged urban air, respectively.

The DOE G-1 and NASA B-200 aircraft flight plans will involve transects over the ground sites in the morning and again in the afternoon. Both aircraft will also sample upwind of the Sacramento urban area to characterize the in-flow boundary conditions into the region of interest. We envision this as the primary sampling strategy that will be employed for many days so that we can obtain representative information. A few sample flight plans are presented in the CARES Science Plan. 


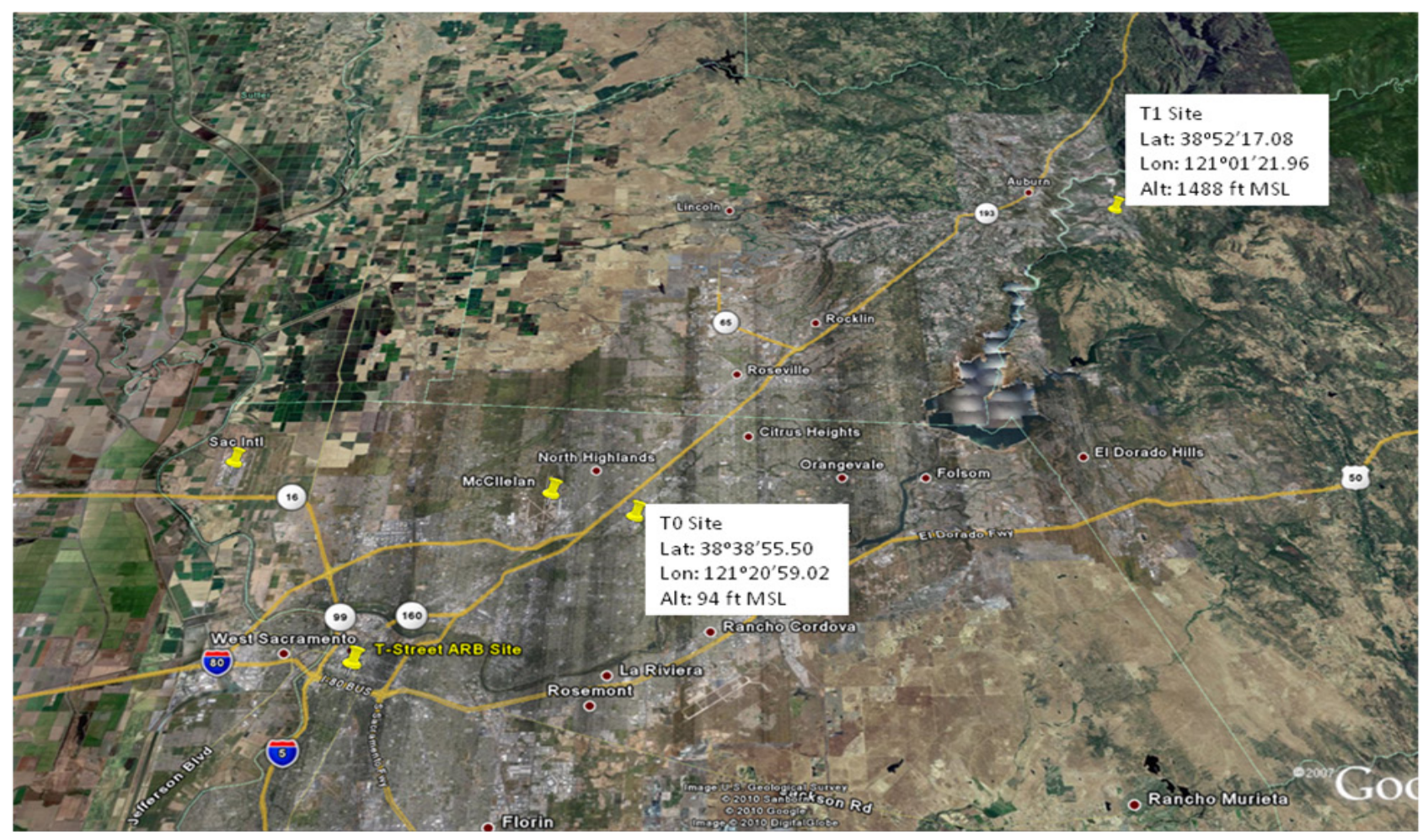

Figure 1. Locations of the planned ground sites (T0 and T1) for CARES.

\subsection{Aircraft Logistics and Instrument Payload}

\subsection{DOE G-1 Aircraft}

The aircraft component of the CARES field campaign will be based out of McClellan Airfield. McClellan Jet Services is contracted to provide adequate office space, conference rooms, internet access, hangar space, and power for the aircraft. Office space includes an Operations Center, scientist office space, a pilots' room, and workspace for working on instruments. Fiber-optic internet connections will be available in each office and conference room.

The G-1 aircraft will fly 72 science flight hours during the CARES campaign. The payload as listed in Table 1 will have the layout shown in Figure 2. The G-1 Research Aircraft Safety Plan has been approved by both Pacific Northwest National Laboratory (PNNL) and DOE. The primary safety concern for this mission is the low-altitude flights (the lowest flight legs are $\sim 1000 \mathrm{ft}$ above ground level). A low-altitude flight waiver has been submitted and approved by the FAA. The flight crew will submit flight plans to air traffic control (ATC) before each flight and work with ATC throughout the campaign to ensure flight safety in the urban Sacramento valley.

There is a potential for cabin temperatures to reach $40^{\circ} \mathrm{C}$ due to ambient air temperatures expected in June in Sacramento Valley, as well as the heat generated by the payload. If cabin temperatures reach unsafe levels for crew members and/or exceed maximum operating thresholds for instruments, the payload will be adjusted based on the critical nature of instruments as related to the overall science plan, and as identified in Table 1. 


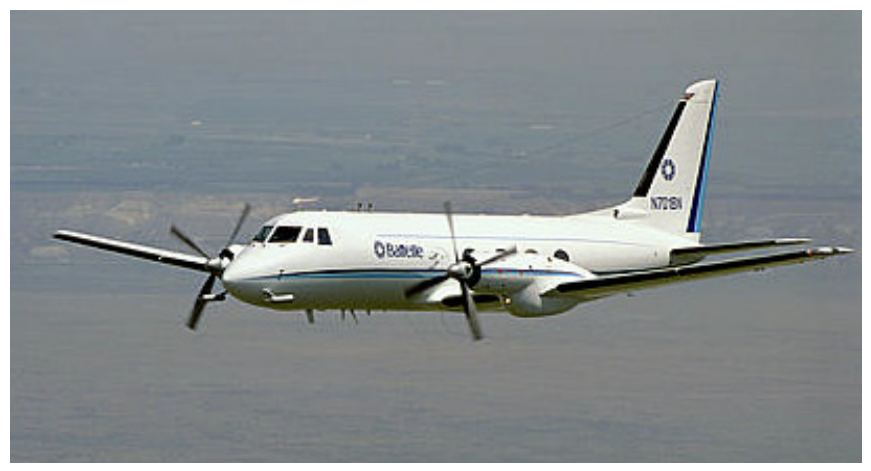

Table 1. List of Planned Measurements and Instruments onboard the DOE G-1 aircraft.

\begin{tabular}{|c|c|c|}
\hline Measurement & Instrument & PI \\
\hline \multicolumn{3}{|l|}{ Meteorology } \\
\hline Temperature & Rosemount 102 & Hubbe (PNNL) \\
\hline Dewpoint temperature & $\begin{array}{l}\text { General Eastern 1011B chilled-mirror } \\
\text { hygrometer }\end{array}$ & Hubbe (PNNL) \\
\hline Absolute humidity & Maycomm Tunable Diode Laser & Hubbe (PNNL) \\
\hline Static pressure & Rosemount 1201F1 & Hubbe (PNNL) \\
\hline Gust probe & Rosemount 1221F2 & Hubbe (PNNL) \\
\hline \multicolumn{3}{|l|}{ Trace Gases } \\
\hline $\mathrm{CO}$ & Resonance Limited VUV-Fluorescence & Springston (BNL) \\
\hline $\mathrm{SO}_{2}$ & TEI $43 \mathrm{~S}$ & Springston (BNL) \\
\hline $\mathrm{O}_{3}$ & TEI 49-100 & Springston (BNL) \\
\hline $\mathrm{NO}, \mathrm{NO}_{2}$, and $\mathrm{NO}_{\mathrm{y}}$ & Research Grade Instruments & Springston (BNL) \\
\hline Hydrocarbon trace gases & PTR-MS & Shilling (PNNL) \\
\hline \multicolumn{3}{|l|}{ Aerosol Size } \\
\hline Number conc. $>3 \mathrm{~nm}$ & TSI-3025 CPC & Comstock/Tomlinson (PNNL) \\
\hline Number conc. $>10 \mathrm{~nm}$ & TSI-3010 CPC & Comstock/Tomlinson (PNNL) \\
\hline PSD: $20-70 \mathrm{~nm}$ & FIMS & Wang (BNL) \\
\hline PSD: $55-1000 \mathrm{~nm}$ & UHSAS & Comstock/Tomlinson (PNNL) \\
\hline PSD: $500-20000 \mathrm{~nm}$ & CAPS/CAS & Senum $(B N L)$ \\
\hline \multicolumn{3}{|l|}{ Aerosol Composition } \\
\hline Aerosol composition & HR-ToF-AMS (EMSL) & Shilling (PNNL) \\
\hline $\begin{array}{l}\text { Single particle composition and } \\
\text { size }\end{array}$ & ATOFMS & Prather (UCSD) \\
\hline Soot mass & SP2 & Sedlacek (BNL) \\
\hline $\begin{array}{l}\text { Water-soluble aerosol chemical } \\
\text { composition }\end{array}$ & PILS with autosampler & Brechtel (BMI) \\
\hline Aerosol Chemical Composition & TRAC Collector & Laskin (EMSL) \\
\hline \multicolumn{3}{|l|}{ Optical Properties } \\
\hline Aerosol light scattering & 3- $\lambda$ TSI 3563 Nephelometer & Hubbe (PNNL) \\
\hline Aerosol light absorption & $3-\lambda$ PSAP & Hubbe (PNNL) \\
\hline $\begin{array}{l}\text { Aerosol light absorption and } \\
\text { scattering }\end{array}$ & $3-\lambda$ PAS $(405,532,870 \mathrm{~nm})$ & Dubey (LANL) \\
\hline
\end{tabular}




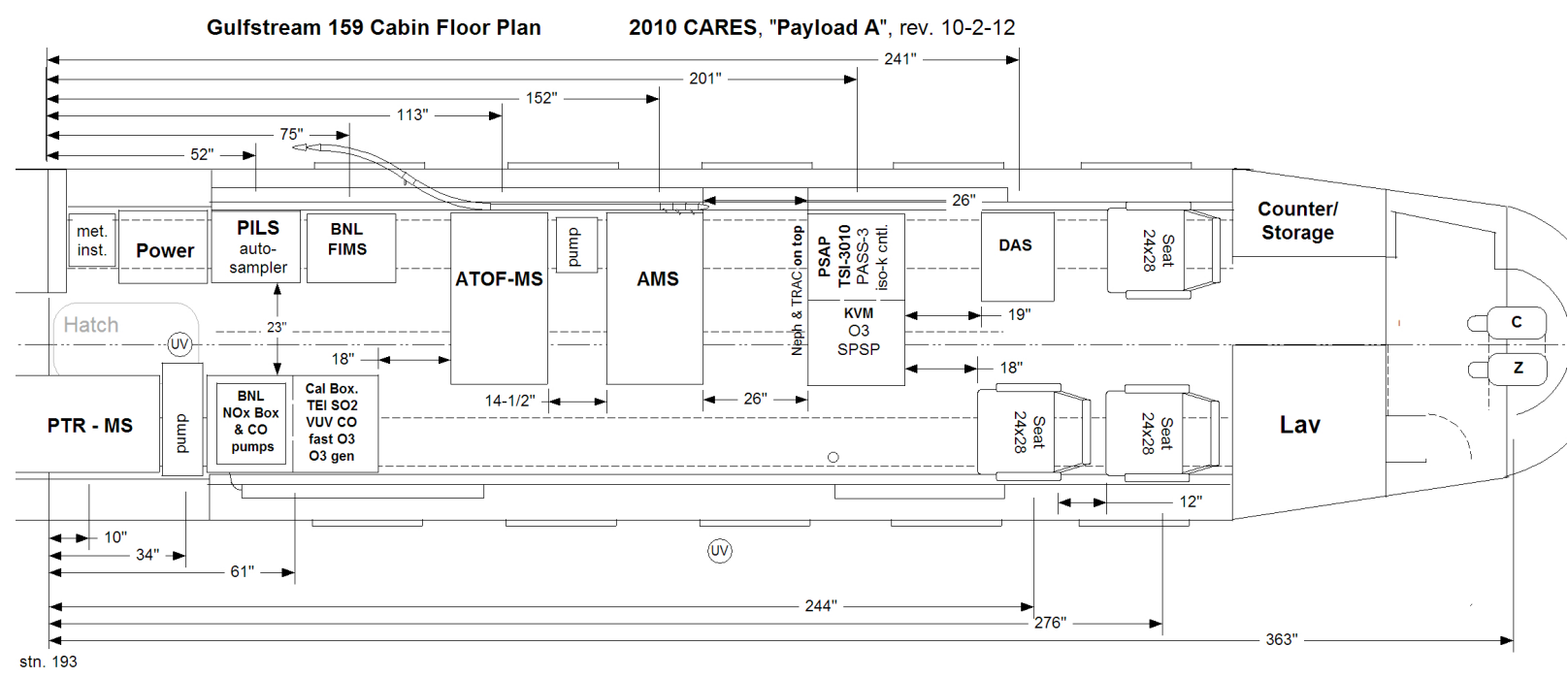

Figure 2. G-1 cabin floor plan for the payload listed in Table 1.

\subsection{NASA B-200 King Air Aircraft}

The majority of G-1 research flights will be coordinated with the NASA B-200 King Air. The King Air flight path will follow that of the G-1, but will operate at $\sim 28,000 \mathrm{ft}$, well above the maximum altitude of the G-1. Although the King Air payload includes a nadir-pointing lidar, the altitude at which the aircraft operates minimizes any potential risk associated with lidar operations.

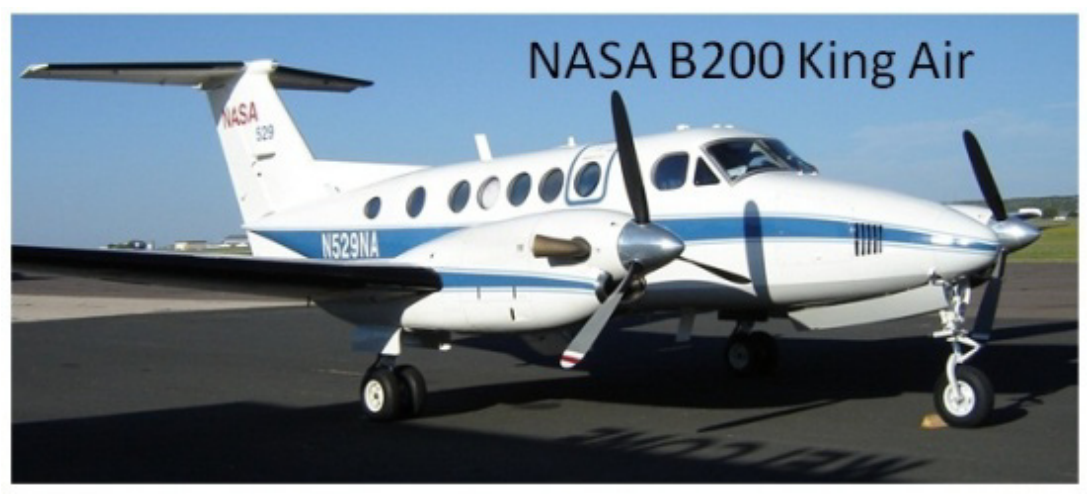

Table 2. List of Planned Measurements and Instruments onboard the NASA B-200 King Air aircraft.

\begin{tabular}{|l|l|l|}
\hline \multicolumn{1}{|c|}{ Measurement } & \multicolumn{1}{c|}{ Instrument } & \multicolumn{1}{c|}{ PI } \\
\hline Backscatter ratio $(532 \mathrm{~nm})$ & High Spectral Resolution Lidar & Ferrare/Hostetler (NASA) \\
\hline Backscatter coefficient $(532 \& 1064 \mathrm{~nm})$ & High Spectral Resolution Lidar & Ferrare/Hostetler (NASA) \\
\hline Extinction coefficient $(532 \mathrm{~nm})$ & High Spectral Resolution Lidar & Ferrare/Hostetler (NASA) \\
\hline Depolarization & High Spectral Resolution Lidar & Ferrare/Hostetler (NASA) \\
\hline Aerosol optical depth & Research Scanning Polarimeter & Cairns (NASA/GISS) \\
\hline
\end{tabular}




\subsection{Ground Sites Logistics and Instruments}

\subsection{T0 Site: American River College, Sacramento, California}

The T0 ground site is located on the campus of American River College (ARC) at 4700 College Oak Drive, Sacramento, California, 95841. The GPS coordinates of the site are: latitude: 38.6487 degrees N, longitude: 121.3497 degrees W.

\subsubsection{Instrument Shelters}

The Atmospheric Radiation Measurement (ARM) Climate Research Facility is providing two contract trailers at $\mathrm{T} 0$. These trailers are $40 \mathrm{ft}$ long and $10 \mathrm{ft}$ wide. They will be equipped with ramps for ease of moving instruments in and out during setup and tear-down. The trailers will be placed side by side to allow the aerosol stack to be erected between them. This will allow for inlet lines to go to each of the trailers from the single stack. Inlet lines from the stack will be provided for both gas and particles. Particle lines will be made of Teflon, and the gas inlet line is stainless steel. Pickoff points are also provided for individual instruments. The complete list of instruments at T0 is given in Table 3 .

\subsubsection{Electrical Power}

Each of the contract trailers contains a 200A service panel for both instruments and air conditioning, and outlets are distributed along the wall on both sides of each trailer. The WSU trailer has a panel capacity of $80 \mathrm{~A}$, which will also be supplied.

\subsubsection{Internet Access}

Broadband internet access will be provided to all participants in each of the trailers. The connection will be wireless to a router installed at a point of presence in a nearby ARC building. Within the trailers, connectivity will be provided by Ethernet connections to a switch in each trailer. The bandwidth will be adequate for transferring small data files and general internet access. Provision will also be made to allow remote monitoring of instruments within each trailer if those instruments are designed to permit such access. Instructions for remote monitoring will be provided at the beginning of the campaign.

\subsubsection{Trailer Layouts and Locations}

The interior trailer layout for T0 is shown in Figure 3. The figure shows the tables (included with the trailer) on which investigators will be able to install their equipment. Specific investigator/instrument locations are also shown in this figure. The trailers will be located in a maintenance parking lot behind the police station at ARC. The location in relation to local buildings is shown in Figure 4. The building in the upper part of the figure has a number of storage bays. The building adjacent to the trailer location is used for various maintenance activities. This location is on the western edge of the campus bounded by College Oak Drive. 
Table 3. List of Planned Measurements and Instruments at T0.

\begin{tabular}{|c|c|c|}
\hline Measurement & Instrument & PI \\
\hline \multicolumn{3}{|l|}{$\overline{\text { Meteorology }}$} \\
\hline Wind profile & Wind Profiler & Berg (PNNL) \\
\hline Temperature, RH profile & Radiosonde & Berg (PNNL) \\
\hline Surface T, P, RH, wind & Vaisala WXT-510 & Jobson (WSU) \\
\hline \multicolumn{3}{|l|}{ Trace Gases (in WSU Shelter) } \\
\hline Hydrocarbon trace gases & PTR-MS & Jobson (WSU) \\
\hline Semi-volatile organic gases & GC-ITMS & Jobson (WSU) \\
\hline $\mathrm{CO}$ & Vacuum UV fluorescence & Jobson (WSU) \\
\hline $\mathrm{O}_{3}$ & UV absorption & Jobson (WSU) \\
\hline $\mathrm{NO}, \mathrm{NO}_{2}, \mathrm{NO}_{\mathrm{y}}$ & Research grade instruments & Jobson (WSU) \\
\hline $\mathrm{SO}_{2}$ & Thermo Model 43i & Song (PNNL) \\
\hline \multicolumn{3}{|l|}{ Aerosol Size } \\
\hline Size distribution & SMPS + CPC: $10 \mathrm{~nm}-1000 \mathrm{~nm}$ & Song (PNNL) \\
\hline Size distribution & APS: $500 \mathrm{~nm}-20000 \mathrm{~nm}$ & Jobson (WSU) \\
\hline \multicolumn{3}{|l|}{ Aerosol Composition } \\
\hline Composition and volatility & HR-ToF-AMS + thermal denuder & Song (PNNL) \\
\hline Aerosol atomizer & & Song (PNNL) \\
\hline Single particle composition & SPLAT II + SMPS & Zelenyuk (EMSL) \\
\hline Soot mass & SP2 (BNL) & Subramanian (DMT) \\
\hline Water-soluble aerosol species & PILS with autosampler & Zhang (UC Davis) \\
\hline Organic and elemental carbon & Sunset OC/EC & Laulainen (PNNL) \\
\hline Aerosol chemical composition & TRAC Collector & Laskin (EMSL), Gilles (LBNL) \\
\hline Aerosol chemical composition & DRUM Sampler & Laskin (EMSL) \\
\hline Aerosol morphology & SEM Collector & Mazzoleni (MTU) \\
\hline Offline CI-ToF-AMS & Hi-vol Filter & Thornton (UW) \\
\hline Aldehydes and polar organics & Hi-vol Filter & Kubatova (UND) \\
\hline \multicolumn{3}{|c|}{ Radiation and Aerosol Optical Properties } \\
\hline $\mathrm{J}-\mathrm{NO}_{2}$ & $4 \pi \mathrm{J}-\mathrm{NO} 2$ radiometer & Laulainen (PNNL) \\
\hline Broadband solar radiation flux & Pyranometer & Berg (PNNL) \\
\hline $\begin{array}{l}\text { Direct normal and diffuse horizontal } \\
\text { and total horizontal solar irradiances }\end{array}$ & MFRSR & Berg (PNNL) \\
\hline Light scattering & Nephelometer & Pekour (PNNL) \\
\hline Light absorption & PSAP & Pekour (PNNL) \\
\hline Light absorption and scattering & PAS-2 $(405,870)$, PA-1047 nm & Arnott (UNR) \\
\hline Light absorption and scattering & PAS-3 $(405,532,870 \mathrm{~nm})+$ thermal denuder & Dubey (LANL) \\
\hline Light absorption and scattering & PAS-3 $(405,532,870 \mathrm{~nm})$, PA-375 nm & Dubey (LANL) \\
\hline Light extinction and scattering & $\mathrm{CRD}(355,532,1064 \mathrm{~nm})$ & Atkinson (PSU) \\
\hline \multicolumn{3}{|l|}{ Hygroscopic \& CCN Properties } \\
\hline Cloud condensation nuclei & CCN Counter & Cziczo (PNNL) \\
\hline Hygroscopic growth & Humidigraph - $\mathrm{f}(\mathrm{RH})$ & Cziczo (PNNL) \\
\hline
\end{tabular}


CARES - T0

Trailer Layout, ver4

$5 / 3 / 2010$

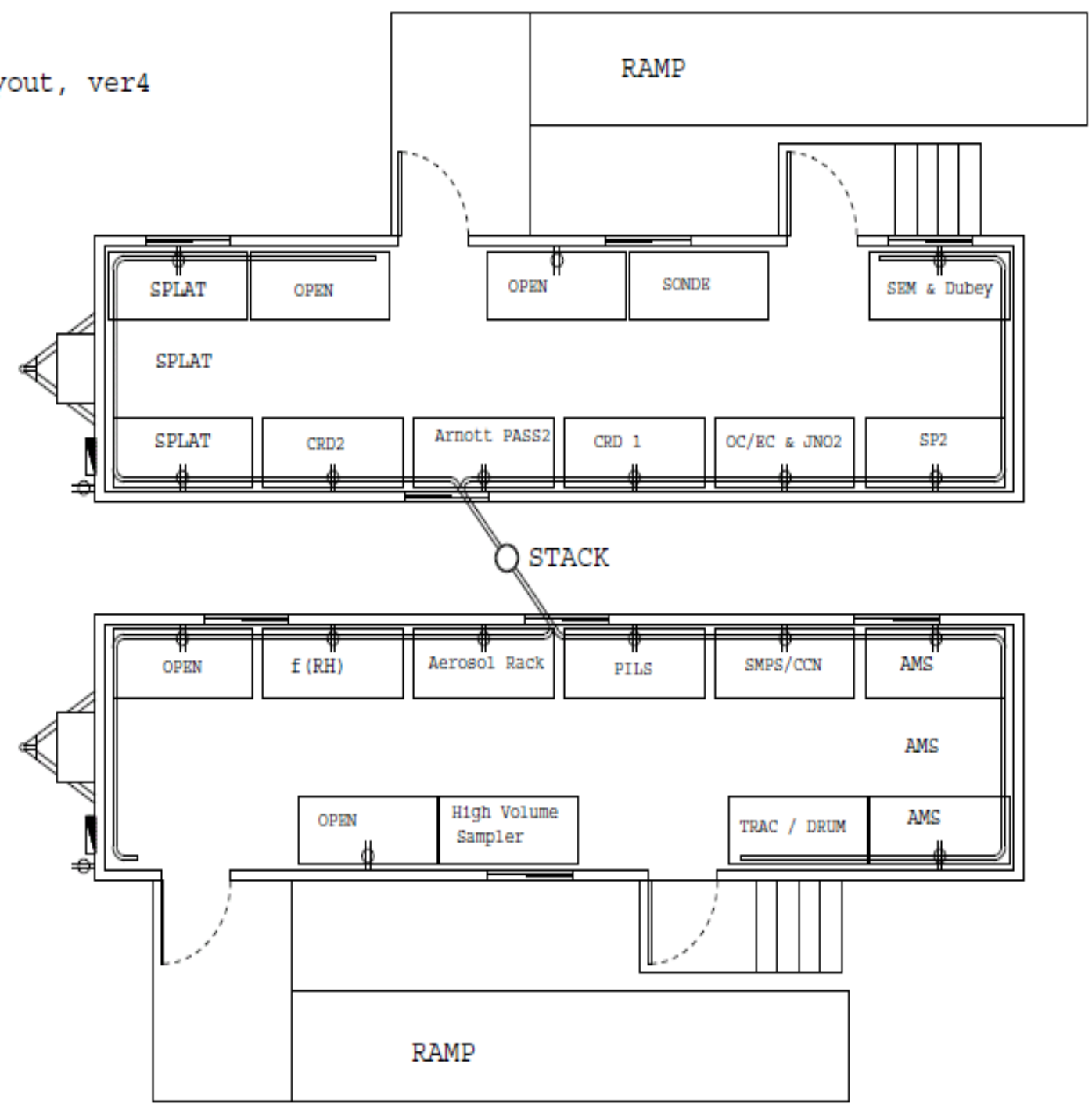

Figure 3. T0 trailer layouts for the instruments. 


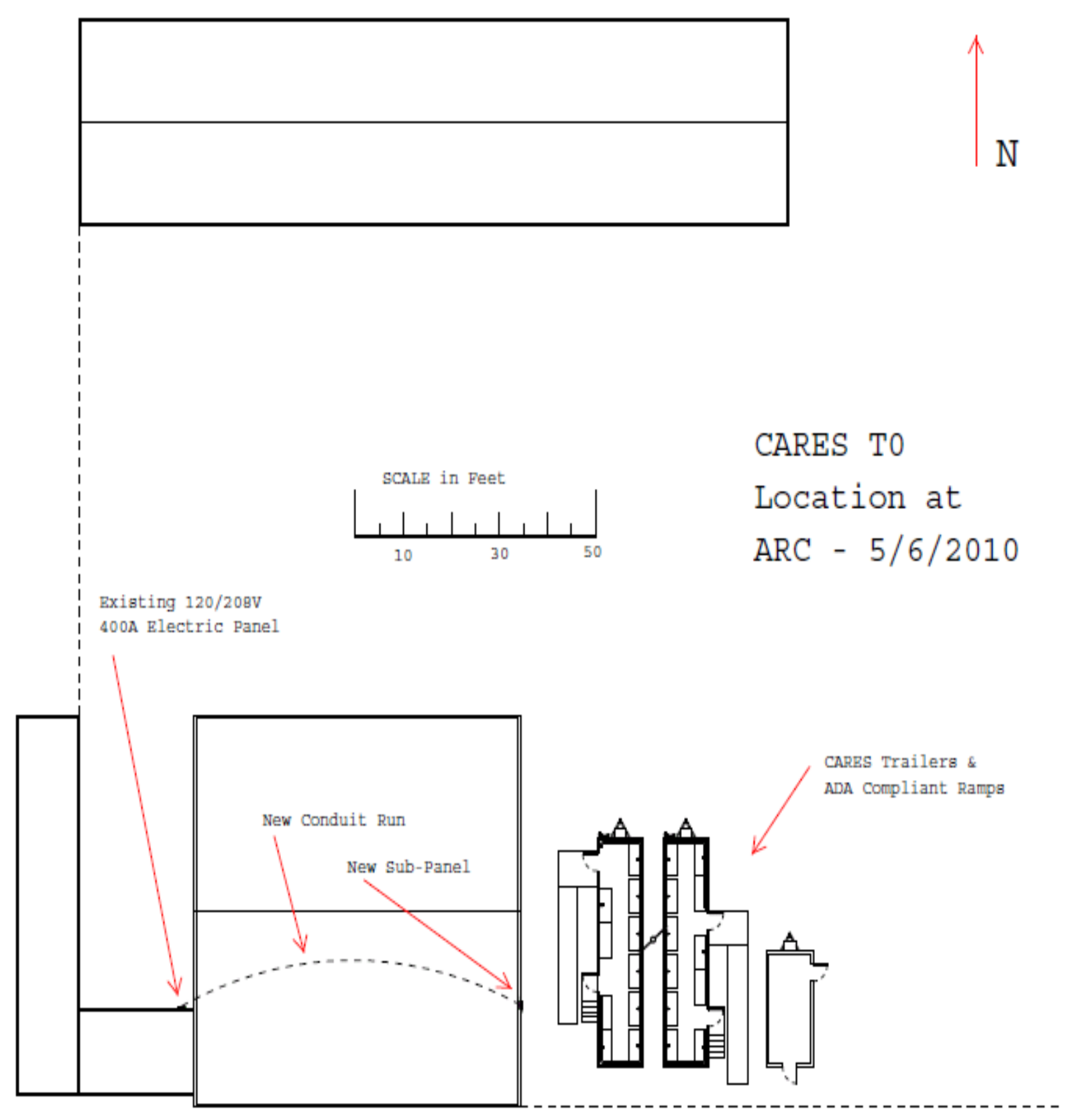

Figure 4. Location of the CARES trailers at the T0 site.

\subsubsection{Security Arrangements}

The measurement site at ARC is located immediately behind the police station, which provides a substantial inherent level of security for the site. In addition, unofficial but uniquely designed photo ID badges will be provided to all participants. This will allow campus personnel to tell at a glance whether individuals in the vicinity of the trailers are legitimate participants in the campaign. All participants will be expected to wear these badges when they are on the site. 


\subsection{T1 Site: Northside School, Cool, California}

The T1 ground site is located on the campus of the Northside School at 860 Cave Valley Road, Cool, California, 95614. The GPS coordinates of the site are: latitude: 38.8714 degrees N, longitude: 121.0227 degrees W.

\subsubsection{Instrument Shelters}

ARM is providing two contract trailers at $\mathrm{T} 1$. These trailers are $40 \mathrm{ft}$ long and $10 \mathrm{ft}$ wide. They will be equipped with ramps for ease of moving instruments in and out during setup and tear-down. The trailers will be placed side by side to allow the aerosol stack to be erected between them. This will allow for inlet lines to go to each of the trailers from the single stack. Inlet lines from the stack will be provided for both gas and particles. Particle lines will be made of Teflon, and the gas inlet line is stainless steel. Pickoff points are also provided for individual instruments. The complete list of instruments at T1 is given in Table 4.

\subsubsection{Electrical Power}

Each of the contract trailers contains a 200A service panel for both instruments and air conditioning, and outlets are distributed along the wall on both sides of each trailer.

\subsubsection{Internet Access}

Broadband internet access will be provided to all participants in each of the trailers. The connection will be wireless to a router installed at a point of presence in a nearby Northside School building. Within the trailers, connectivity will be provided by Ethernet connections to a switch in each trailer. The bandwidth will be adequate for transferring small data files and general internet access. Provision will also be made to allow remote monitoring of instruments within each trailer if those instruments are designed to permit such access. Instructions for remote monitoring will be provided at the beginning of the campaign.

\subsubsection{Trailer Layouts and Locations}

The interior trailer layout for T1 is shown in Figure 5. The figure shows the tables (included with the trailer) on which investigators will be able to install their equipment. Specific investigator/instrument locations are also shown in this figure.

The trailers will be located in a maintenance parking lot south of the Northside School campus buildings. The location in relation to southernmost classrooms is shown in Figure 6. This location is on the west side of Highway 49 south of Cool. 
Table 4. List of Planned Measurements and Instruments at T1.

\begin{tabular}{|c|c|c|}
\hline Measurement & Instrument & PI \\
\hline \multicolumn{3}{|l|}{ Meteorology } \\
\hline Wind profile & Sodar & Berg (PNNL) \\
\hline Temperature, $\mathrm{RH}$ profile & Radiosonde & Berg (PNNL) \\
\hline Surface T, P, RH, wind & Met Station & Berg (PNNL) \\
\hline \multicolumn{3}{|l|}{ Trace Gases } \\
\hline Hydrocarbon trace gases & PTR-MS & Knighton (MSU) \\
\hline $\mathrm{CO}$ & Teledyne Model 300U CO Analyzer & Dubey (LANL) \\
\hline $\mathrm{CO}_{2}-\mathrm{CH}_{4}-\mathrm{H}_{2} \mathrm{O}$ & Picarro Cavity Ringdown Analyzer & Dubey (LANL) \\
\hline $\mathrm{O} 3$ (PNNL) & Chen Song will calibrate instrument & Dubey (LANL) \\
\hline $\mathrm{NO}, \mathrm{NO}_{\mathrm{y}}$ & Research grade instruments & Dubey (LANL) \\
\hline \multicolumn{3}{|l|}{ Aerosol Size } \\
\hline Size distribution & SMPS: $10 \mathrm{~nm}-1000 \mathrm{~nm}$ & Onasch (Aerodyne) \\
\hline Size distribution & APS: $500 \mathrm{~nm}-20000 \mathrm{~nm}$ & Pekour (PNNL) \\
\hline \multicolumn{3}{|l|}{ Aerosol Composition } \\
\hline Composition and volatility & HR-ToF-AMS + thermal denuder & Onasch (Aerodyne) \\
\hline Single particle composition & PALMS & Cziczo (PNNL) \\
\hline Soot mass & SP2 & Subramanian (DMT) \\
\hline Water-soluble aerosol species & PILS with autosampler & Zhang (UC Davis) \\
\hline Organic and elemental carbon & Sunset OC/EC & Laulainen (PNNL) \\
\hline Aerosol chemical composition & TRAC & Laskin (EMSL), Gilles (LBNL) \\
\hline Aerosol chemical composition & DRUM Sampler & Laskin (EMSL) \\
\hline Aerosol morphology & SEM Collector & Mazzoleni (MTU) \\
\hline Aldehydes and polar organics & Hi-vol Filter & Kubatova (UND) \\
\hline Radiocarbon & Hi-vol Filter & Gaffney (U Ark) \\
\hline Dissolved organics in rainwater & Wet/Dry Collector for precip. & Gaffney (U Ark) \\
\hline \multicolumn{3}{|c|}{ Radiation and Aerosol Optical Properties } \\
\hline Actinic flux & Diode-Array Spectroradiometer & Laulainen (PNNL) \\
\hline Broadband solar radiation flux & Pyranometer & Barnard (PNNL) \\
\hline $\begin{array}{l}\text { Direct normal and diffuse horizontal } \\
\text { and total horizontal solar irradiances }\end{array}$ & MFRSR & Pekour (PNNL) \\
\hline Light scattering & Nephelometer & Pekour (PNNL) \\
\hline Light absorption & Athelometer & Sedlacek (BNL) \\
\hline Light absorption & PSAP & Pekour (PNNL) \\
\hline Light absorption and scattering & PA-355, PA-532, PA-870 & Arnott (UNR) \\
\hline Light absorption and scattering & $\begin{array}{l}\text { PAS-3 }(405,532,870 \mathrm{~nm}), \text { PA-375 nm + } \\
\text { thermal denuder }\end{array}$ & Dubey (LANL) \\
\hline Light extinction and scattering & CRD $(355,532,1064 \mathrm{~nm})$ & Atkinson (PSU) \\
\hline \multicolumn{3}{|l|}{ Hygroscopic \& CCN Properties } \\
\hline Cloud condensation nuclei & CCN Counter & Cziczo (PNNL) \\
\hline Hygroscopic growth & Humidigraph - $\mathrm{f}(\mathrm{RH})$ & Cziczo (PNNL) \\
\hline Size-selected CCN & SCCN Counter & Wang (BNL) \\
\hline
\end{tabular}


CARES - T1

Trailer Layout, ver5

$5 / 3 / 2010$

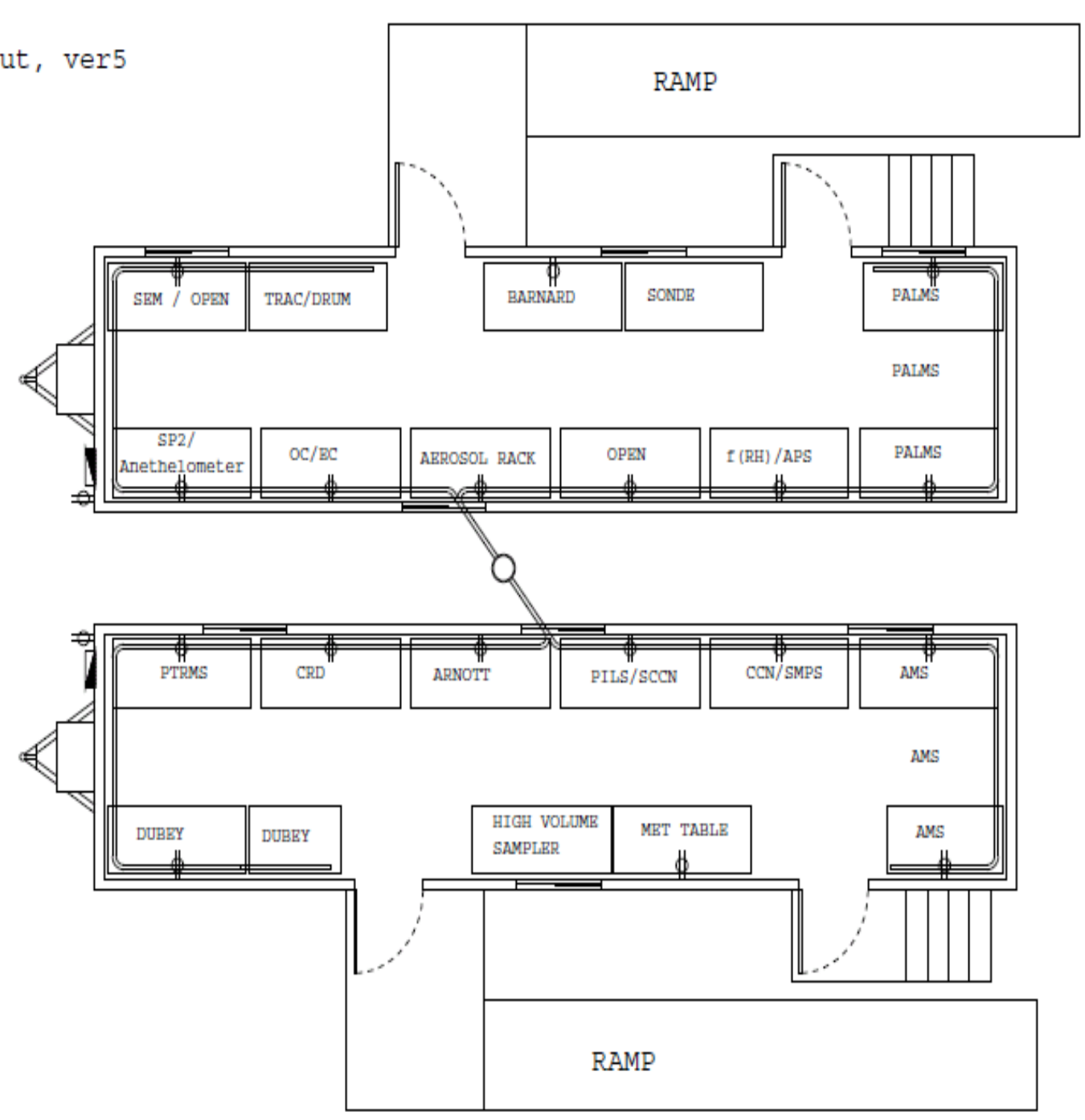

Figure 5. T1 trailer layouts for the instruments. 


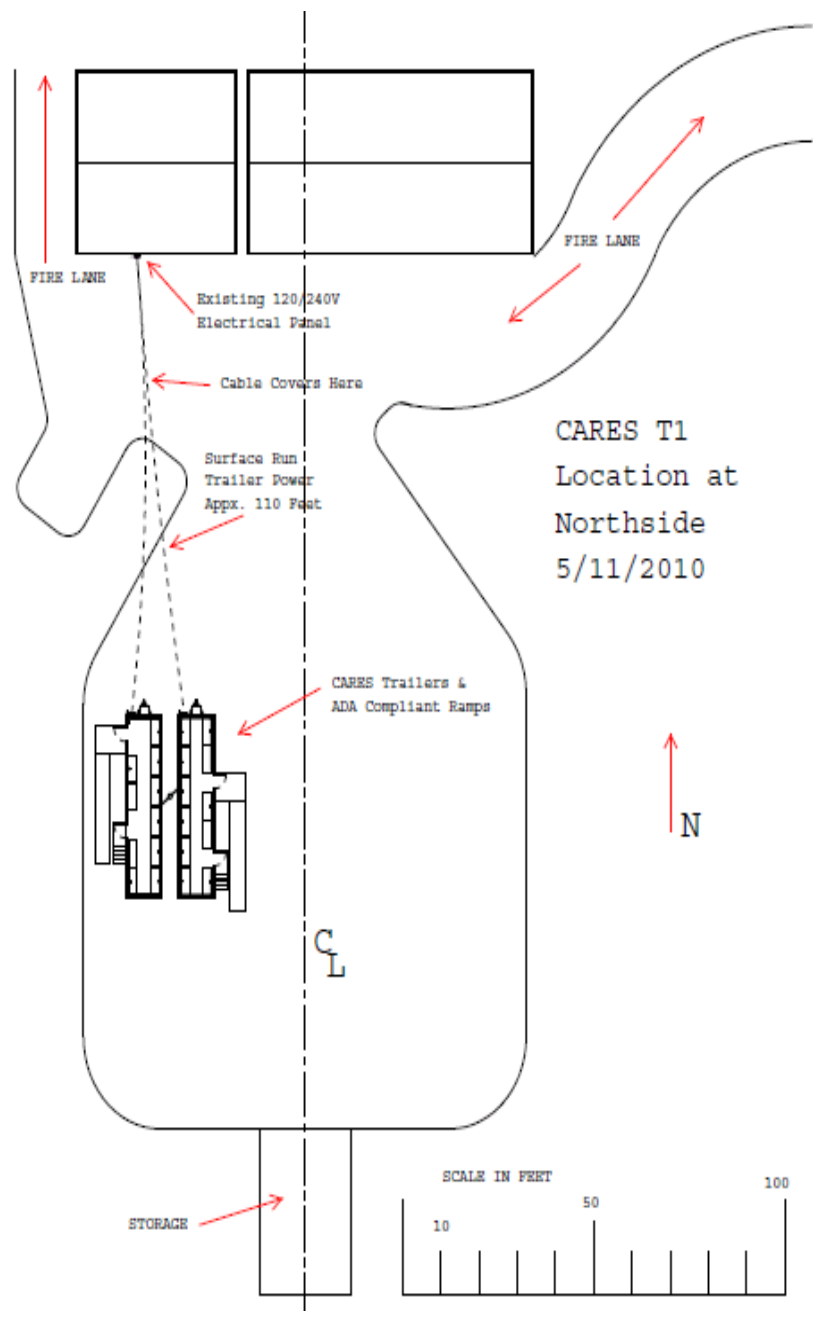

Figure 6. Location of the CARES trailers at the T1 site.

\subsubsection{Security Arrangements}

The measurement site at Northside School is out of sight of Highway 49. However, its location will be well known to the school students (grades K-8), even though the area is off-limits to them. To provide a measure of security from student curiosity and protection for them as well, the trailers and outdoor sensors will be surrounded by a chain-link fence with lockable gates. The same photo ID badges used at T0 will be provided to all T1 participants. This will allow school personnel to tell at a glance whether individuals in the vicinity of the trailers are legitimate participants in the campaign. All participants will be expected to wear these badges when they are on the site. In addition, Northside School has requested that all CARES participants who enter school grounds during school office hours sign in and out through the office, and all participants will be expected to honor that request.

\subsection{Weather Briefing}

The designated CARES meteorologist (Jerome Fast of PNNL) will be responsible for assembling information regarding the predicted meteorological conditions and expected transport of local pollutants 
in the vicinity of Sacramento for the upcoming several days. The information in the weather briefing will be based on observed meteorological conditions and guidance from several operational model forecasts. For example, NOAA has already deployed a radar wind profiler Sacramento that produces graphics depicting the observed wind profiles in near-real time. These observations, as well as other select CARES measurements (e.g., radar wind profiler at T1, sodar at airport, and radiosondes at T0 and T1) that will be made available via the internet, will be used to assess what can be expected in near-real time as well as assess the accuracy of weather forecast products. There are numerous weather forecast products available on the internet that the lead forecaster will use. These forecast products will be supplemented with a suite of numerical forecast models to be run during June 2010, including the WRF model by PNNL and the WRF-Chem model by NOAA for CalNex. Although PNNL and NOAA are using the same model, it will be run in different configurations to suit the needs of each field campaign.

The first task of the weather briefing is to determine whether any changes in the latest operational forecast models will lead to canceling flights on the same day. The second task of the briefing will be to discuss whether the meteorological conditions are favorable for transport from the T0 to $\mathrm{T} 1$ sites and photochemical production during the upcoming several days. A forecaster from the local California Air Resource Board (CARB) office may be available at the briefings to provide information on planned agricultural burning events in the surrounding areas. Based on the weather briefing, the field campaign principal investigator and ARM Aerial Facility (AAF) representatives will decide whether to schedule G1 flights for the upcoming days. Copies of the weather briefing will be posted on the ARM field campaign site so that all investigators at the $\mathrm{T} 0$ and $\mathrm{T} 1$ sites and other offsite scientists can view the material. Although measurements will be taken continuously at the T0 and T1 sites, the field campaign principal investigator will contact the lead scientists of the two sampling sites to inform them of the planned flight operations. The CARES meteorologist will also be available during the day to assist the field campaign principal investigator with the interpretation of the latest meteorological conditions that may affect afternoon operations of the G-1.

\subsection{WRF Forecast Model}

PNNL will use the Weather Research and Forecasting (WRF) model to provide forecasts of tracer plumes based on $\mathrm{CO}$ emissions as well as meteorological parameters, using a horizontal grid spacing of $4 \mathrm{~km}$. The tracers will be based on source region, with emissions from various anthropogenic emission sources that could impact the sampling in the vicinity of Sacramento. Given the model configuration shown in Figure 7, 72-hour forecasts will be made once per day using the 00 UTC GFS forecasts as initial and boundary conditions. The 00 UTC GFS forecast is expected to become available around midnight local time. Shortly after midnight, a script will download the GFS forecast, process the initial and boundary conditions needed by WRF, and perform a 72-hour tracer forecast. Tracers will be initialized with the previous forecast positions at 00 UTC. After the WRF forecast is completed, graphics depicting tracer positions at the surface and at select altitudes will be generated automatically. An example plot of the tracers for one time is shown in Figure 8. These graphics will be transferred to an ARM web page so that they may be viewed via the internet. The overall process of creating a forecast is shown in Figure 9, and the total time to execute the script is expected to take $4-5$ hours, so that the forecast will be available by 06 LST.

These forecasts will be used to help guide aircraft operations by determining what days are favorable for transport from Sacramento to Cool and how much material is expected from more aged sources, such as 
the Bay Area, San Joaquin Valley, and Sacramento Valley. The spatial extent of the plumes will help determine whether the planned aircraft flight plans need to be adjusted based on the anticipated upcoming meteorological conditions.

Pre-field campaign modeling has been performed using the WRF tracer model configuration to simulate the conditions during June-August 2009. The tracer forecasts have been coupled with observed CARB measurements of ozone, PM2.5, and meteorological conditions to understand the expected accuracy of the forecasts as well as better understand the relationship between the near-surface and upper-level winds. The simulation results and the observed CARB data both showed that meteorological conditions for transport from T0 and T1 are favorable on the majority of days in June. When the upslope flow does not occur, pollutants from Sacramento are likely to be transported towards the southeast into the San Joaquin Valley.
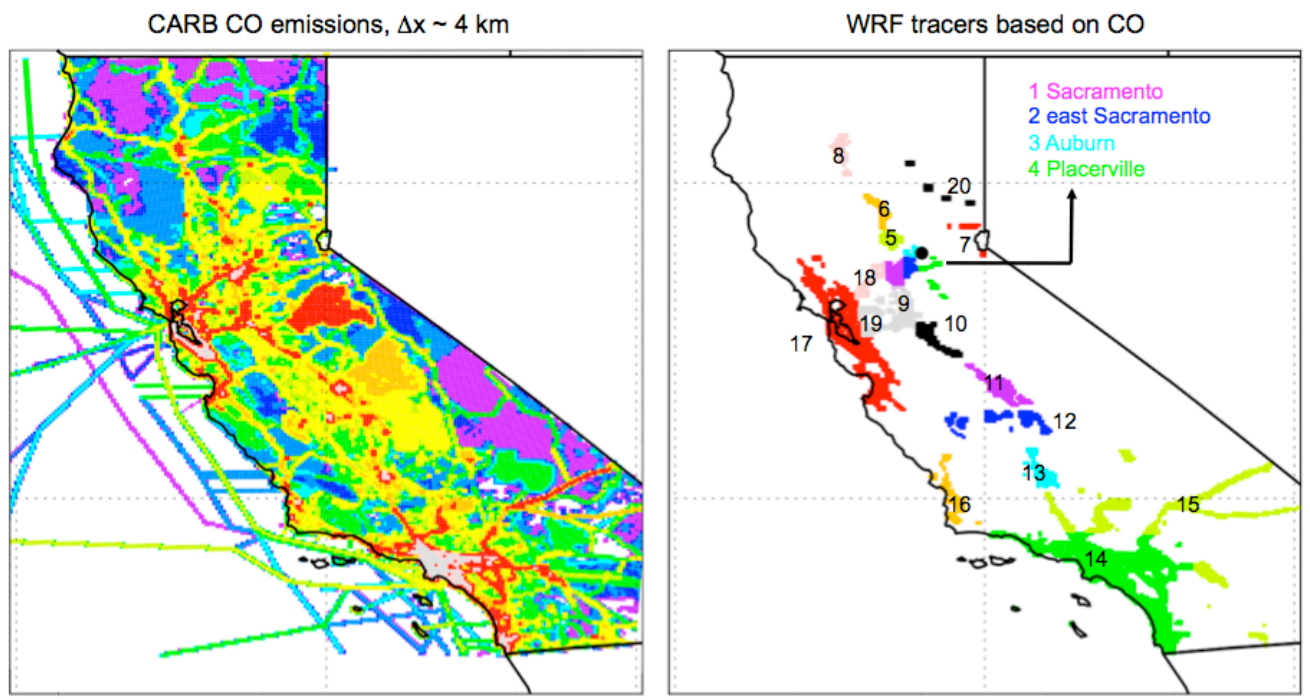

Figure 7. Domain of the WRF tracer forecast model using a horizontal grid spacing of $4 \mathrm{~km}$ and $280 \mathrm{x}$ 280 x 65 points. Left panel depicts $\mathrm{CO}$ emissions from the California Air Resources Board (CARB), and the right panel depicts the 20 tracers defined by source region with relatively high $\mathrm{CO}$ emissions. 

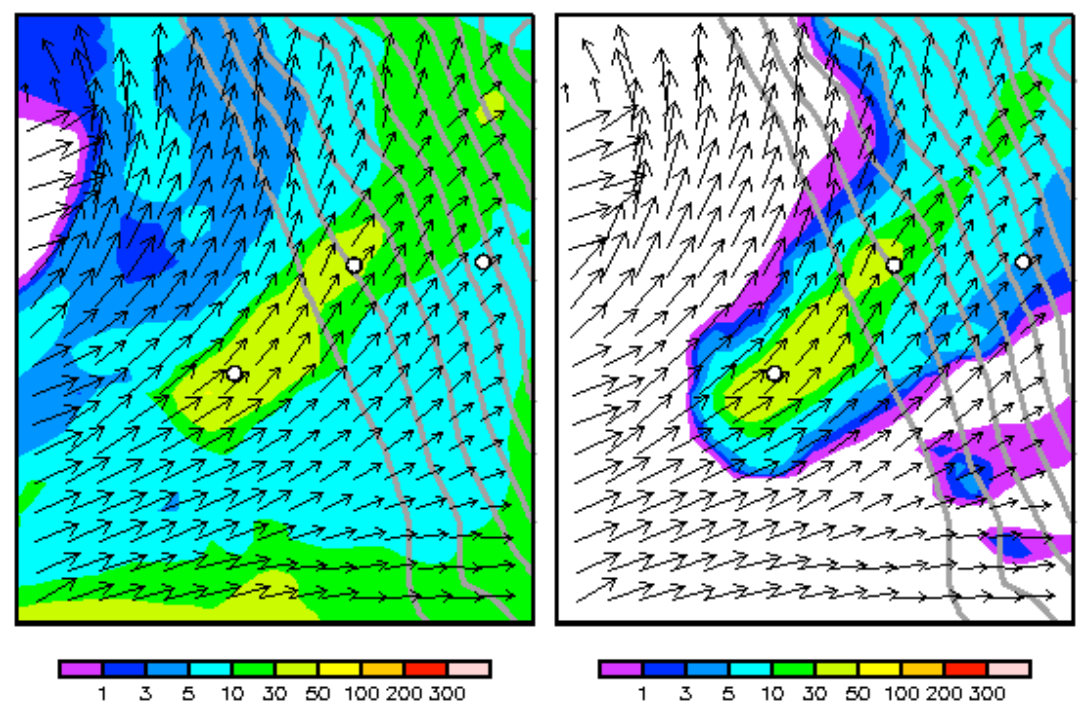

Figure 8. Example tracer forecast depicting simulated $\mathrm{CO}$ from all sources (left panel) and those from local sources (right panel). The dots denote the T0, T1, and Blodgett Forest sites.

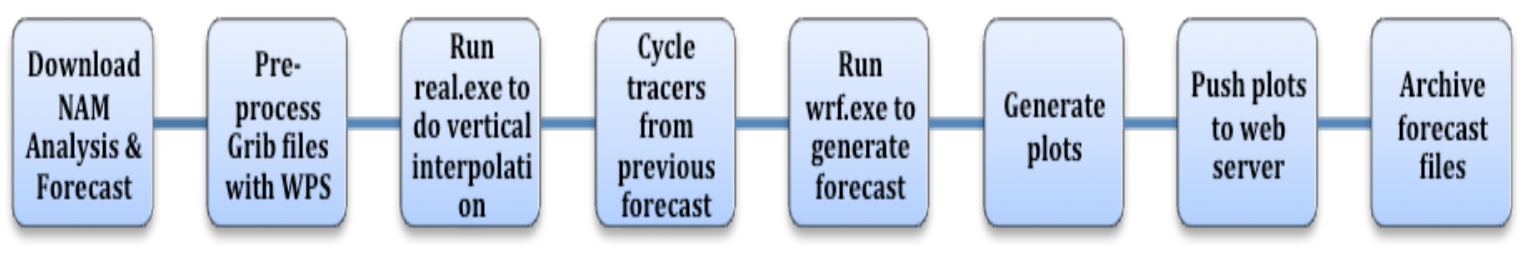

Figure 9. Diagram listing the steps needed to generate a forecast from WRF.

\subsection{Other Operational Forecast Models}

The PNNL forecaster will also participate in the CalNex weather briefings and access other operational forecast products being run for CalNex by NOAA that will be available in near-real time. NOAA will use the chemistry version of WRF, WRF-Chem, which will produce forecasts of ozone and particulate matter over California. These products will be used to identify favorable sampling conditions over the Sacramento region over several days.

\subsection{Daily Aircraft Operations}

This section describes the chain of command and responsibilities of personnel involved in CARES routine aircraft operations that include: the weather briefing teleconference, go/no-go decision, flight debriefing, and recording summaries of the flight conditions and operations. Modifications may be needed to respond to unforeseen needs as they arise. 


\subsection{Daily Schedule}

There will be two flights on a typical flight day — one in the morning and another in the afternoon. On a day on which we have decided that flights are likely, we will have the first weather briefing from the CARES meteorologist at 8:00 a.m. This briefing will be focused on the updated forecast for the Sacramento and Bay Area plumes on that day. Shortly after this briefing, a go/no-go decision for the day's first flight will be made, and the takeoff time will be set. At least in the early stages of the deployment, the go/no-go decision will depend on the following criteria:

- Likelihood of T0-T1 or other desired transport pattern for the Sacramento/Bay Area plume based on the latest meteorological information

- Severe weather near takeoff or landing times, or in the vicinity of the operations area. Severe weather may include wild fires in close proximity to the airport

- Too many critical instruments are down.

After the first preflight weather briefing/teleconference, the CARES meteorologist will continue to watch the day's weather and prepare a second weather briefing to occur at noon. Shortly after this briefing, there will be a debriefing from the first flight. Shortly thereafter, a go/no-go decision for the second flight will be made, and the takeoff time will be set. The go/no-go decision will again depend on the same criteria listed above and include the instrument importance rating listed below in Table 5. Based on the proper function of the critical instruments and configuration onboard, the principal investigator will make the decision before the flight for a go or no-go. The PI will brief the cabin crew of proper course of action to take in flight in case of instrument malfunction. 
Table 5. Instrument Importance Rating. Critical: 1, Secondary: 2, Non-critical: 3.

\begin{tabular}{|c|c|c|}
\hline Measurement & Instrument & Rating \\
\hline \multicolumn{3}{|l|}{ Meteorology } \\
\hline Temperature & Rosemount 102 & 1 \\
\hline Dewpoint temperature & $\begin{array}{c}\text { General Eastern } 1011 \mathrm{~B} \text { chilled-mirror } \\
\text { hygrometer }\end{array}$ & 1 \\
\hline Absolute humidity & Maycomm Tunable Diode Laser & 3 \\
\hline Static pressure & Rosemount 1201F1 & 1 \\
\hline Gust probe & Rosemount 1221F2 & 3 \\
\hline \multicolumn{3}{|l|}{ Trace Gases } \\
\hline $\mathrm{CO}$ & Resonance Limited VUV-Fluorescence & 1 \\
\hline $\mathrm{SO}_{2}$ & TEI 43S & 3 \\
\hline $\mathrm{O}_{3}$ & TEI 49-100 & 2 \\
\hline $\mathrm{NO}, \mathrm{NO}_{2}$, and $\mathrm{NO}_{\mathrm{y}}$ & Research Grade Instruments & 2 \\
\hline Hydrocarbon trace gases & PTR-MS & 1 \\
\hline \multicolumn{3}{|l|}{ Aerosol Size } \\
\hline Number conc. $>3 \mathrm{~nm}$ & TSI-3025 CPC & 2 \\
\hline Number conc. $>10 \mathrm{~nm}$ & TSI-3010 CPC & 2 \\
\hline PSD: $20-70 \mathrm{~nm}$ & FIMS & 1 \\
\hline PSD: $55-1000 \mathrm{~nm}$ & UHSAS & 1 \\
\hline PSD: 500-20000 nm & CAPS/CAS & 2 \\
\hline \multicolumn{3}{|l|}{ Aerosol Composition } \\
\hline Aerosol composition & HR-ToF-AMS (EMSL) & 1 \\
\hline $\begin{array}{l}\text { Single particle composition } \\
\text { and size }\end{array}$ & ATOFMS & 1 \\
\hline Soot mass & SP2 & 1 \\
\hline $\begin{array}{l}\text { Water-soluble aerosol chemical } \\
\text { composition }\end{array}$ & PILS with autosampler & 1 \\
\hline Aerosol chemical composition & TRAC Collector & 2 \\
\hline \multicolumn{3}{|l|}{ Optical Properties } \\
\hline Aerosol light scattering & 3- $\square$ TSI 3563 Nephelometer & 1 \\
\hline Aerosol light absorption & 3- $\square$ PSAP & 1 \\
\hline $\begin{array}{l}\text { Aerosol light absorption and } \\
\text { scattering }\end{array}$ & 3- $\square$ PAS $(405,532,870 \mathrm{~nm})$ & 1 \\
\hline
\end{tabular}

The CARES meteorologist will then focus on the updated weather outlook for the next day, the next week, and the rest of the campaign period, and give another weather briefing at 4:00 pm. Shortly after this final briefing, a decision will be made whether to stand up for a flight the following day, and a preliminary flight plan will be determined and communicated to the pilot via the AAF representative. Debriefing from the second flight will only occur if necessary. Otherwise, debriefs will be provided in the pilot notes on the wiki page, and the science team can ask questions during the next morning on a down day. A typical flight day schedule is described in Table 6. A flight crew is dedicated for the morning flight and a second flight crew for the afternoon flight. Onboard scientists may alternate for morning and afternoon flights as well. 
Table 6. Template for Daily Schedule.

\begin{tabular}{|c|c|c|c|c|c|c|c|c|c|}
\hline Time & Event & $\begin{array}{l}\text { Mission PIs } \\
\text { Technical } \\
\text { Directors }\end{array}$ & $\begin{array}{l}\text { Flight } \\
\text { Crew } 1\end{array}$ & Hrs & $\begin{array}{l}\text { Flight } \\
\text { Crew } 2\end{array}$ & Hrs & Scientist & $\begin{array}{l}\text { Ground } \\
\text { crew }\end{array}$ & Hrs \\
\hline $\begin{array}{l}\text { Night } \\
\text { before }\end{array}$ & Pilot files flight plans & & & & & & & & \\
\hline $6: 00$ & $\begin{array}{l}\text { Aircraft access / Instrument } \\
\text { startup }\end{array}$ & & & & & & & $\begin{array}{l}\text { Celine } \\
\text { Kluzek }\end{array}$ & 0.75 \\
\hline $6: 45$ & Weather briefing & & & & & & $\begin{array}{l}\text { Jerome } \\
\text { Fast }\end{array}$ & & 0.25 \\
\hline 7:00 & $\begin{array}{l}\text { Go-No Go decision } \\
\text { Pilot confirms flight plan }\end{array}$ & $\begin{array}{l}\text { Rahul } \\
\text { Zaveri, } \\
\text { Beat } \\
\text { Schmid, } \\
\text { or Jennifer } \\
\text { Comstock }\end{array}$ & $\begin{array}{l}\text { Mike } \\
\text { Hubbell+ } \\
\text { Dick } \\
\text { Hone }\end{array}$ & 1.5 & & & $\begin{array}{l}\text { Example: } \\
\text { John } \\
\text { Shilling }\end{array}$ & & 1.5 \\
\hline $8: 30$ & $\begin{array}{l}\text { Ground checklist completed } \\
\text { Crew boarding }\end{array}$ & & & 0.25 & & & & & 0.25 \\
\hline $8: 45$ & Aircraft door closed & & & 0.25 & & & & & 0.25 \\
\hline \multirow[t]{2}{*}{$9 \mathrm{am}$} & TAKE-OFF & & & & & & & & \\
\hline & $\begin{array}{l}\text { Check weather for second } \\
\text { flight } \\
\text { Rest time for ground crew }\end{array}$ & & & & & & & & \\
\hline $13: 00$ & LANDING & & & 4 & & & & $\begin{array}{c}\text { Jason } \\
\text { Tonlinson }\end{array}$ & 4 \\
\hline $13: 30$ & $\begin{array}{l}\text { Debriefing first flight } \\
\text { Go/No-Go decision for second } \\
\text { flight }\end{array}$ & $\begin{array}{c}\text { Rahul } \\
\text { Zaveri } \\
\text { Beat } \\
\text { Schmid } \\
\text { Jennifer } \\
\text { Comstock }\end{array}$ & $\begin{array}{c}\text { Mike } \\
\text { Hubbell+ } \\
\text { Dick } \\
\text { Hone }\end{array}$ & 0.5 & $\begin{array}{l}\text { Bob } \\
\text { Hannigan } \\
+ \text { Bill } \\
\text { Svancara }\end{array}$ & 0.5 & & & 0.5 \\
\hline $15: 00$ & $\begin{array}{l}\text { Ground checklist completed } \\
\text { Crew boarding }\end{array}$ & & & & & 1.5 & & & 1.5 \\
\hline $15: 15$ & Aircraft door closed & & & & & 0.25 & & & 0.25 \\
\hline \multirow[t]{2}{*}{$15: 30$} & TAKE-OFF & & & & & 0.25 & & $\begin{array}{l}\text { Celine } \\
\text { Kluzek }\end{array}$ & 0.25 \\
\hline & Rest time for ground crew & & & & & & & & \\
\hline $16: 00$ & Science meeting & $\begin{array}{l}\text { Rahul } \\
\text { Zaveri, } \\
\text { Beat } \\
\text { Schmid, } \\
\text { or Jennifer } \\
\text { Comstock }\end{array}$ & & & & & & & \\
\hline $19: 30$ & Landing & & & & & 4 & & & 4 \\
\hline 20:00 & Debriefing second flight & $\begin{array}{l}\text { Rahul } \\
\text { Zaveri, } \\
\text { Beat } \\
\text { Schmid, } \\
\text { or Jennifer } \\
\text { Comstock }\end{array}$ & & & $\begin{array}{l}\text { Bob } \\
\text { Hannigan } \\
+ \text { Bill } \\
\text { Svancara }\end{array}$ & 0.5 & $\begin{array}{l}\text { Example: } \\
\text { John } \\
\text { Shilling }\end{array}$ & & 0.5 \\
\hline \multirow[t]{2}{*}{$21: 00$} & $\begin{array}{l}\text { Download data to network } \\
\text { storage drive }\end{array}$ & & & & & & & $\begin{array}{l}\text { Jason } \\
\text { Tomlinson }\end{array}$ & 1 \\
\hline & & & Totals & 6.5 & & 7 & & & 14 \\
\hline
\end{tabular}

\subsubsection{Tentative schedule for the CARES campaign June $2-28^{\text {th }} 2010,4$ weeks}

The campaign will start with week plan A shown in Table 7. With a minimum of 21 hours of flight time a week, the contract can be completed in less than 4 weeks. Starting with a reasonable schedule will enable the scientists to rest from the instruments integration (week of May $24^{\text {th }}$ ) and enable instrument fixes if 
necessary during soft down days as well as data quality check. Following the first week, plan B can be adopted for one week. Depending on the weather patterns, the cabin crew fatigue levels and the hours of flight time executed, the schedule will be adjusted to meet the 72 hours of total flight time.

Table 7. Template for Monthly Schedule.

\begin{tabular}{|c|c|c|c|}
\hline Day & Event & $\begin{array}{l}\text { Science } \\
\text { Meeting }\end{array}$ & $\begin{array}{l}\text { Flight } \\
\text { hours }\end{array}$ \\
\hline \multicolumn{4}{|l|}{ Week Plan A } \\
\hline Night before & $\begin{array}{l}\text { Pilot files flight plans decided the last flight } \\
\text { day }\end{array}$ & & \\
\hline Wednesday & 2 flights & $\mathrm{X}$ & 7 \\
\hline Thursday & $\begin{array}{l}\text { Soft down day (no flight). Hangar access: } 10 \\
\text { a.m. to } 4 \text { p.m. }\end{array}$ & $\mathrm{X}$ & \\
\hline Friday & 2 flights & $\mathrm{X}$ & 7 \\
\hline Saturday & $\begin{array}{l}\text { Soft down day (no flight). Hangar access: } 10 \\
\text { a.m. to } 4 \text { p.m. }\end{array}$ & $\mathrm{X}$ & \\
\hline Sunday & $\begin{array}{l}\text { Hard down day. No flight, no meeting, no } \\
\text { hangar access }\end{array}$ & & \\
\hline Monday & 2 flights & $\mathrm{X}$ & 7 \\
\hline \multirow[t]{2}{*}{ Tuesday } & $\begin{array}{l}\text { Soft down day (no flight). Hangar access: } 10 \\
\text { a.m. to } 4 \text { p.m. }\end{array}$ & $\mathrm{X}$ & \\
\hline & & Total & 21 \\
\hline \multicolumn{4}{|l|}{ Week Plan B } \\
\hline Night before & Pilot files flight plans & & \\
\hline Wednesday & 2 flights & $\mathrm{X}$ & 7 \\
\hline Thursday & 2 flights & $\mathrm{X}$ & 7 \\
\hline Friday & $\begin{array}{l}\text { Soft down day (possibly one flight). Hangar } \\
\text { access: } 10 \text { a.m. to } 4 \text { p.m. }\end{array}$ & $\mathrm{X}$ & 3.5 \\
\hline Saturday & 2 flights & $\mathrm{X}$ & 7 \\
\hline Sunday & $\begin{array}{l}\text { Hard down day. No flight, no meeting, no } \\
\text { hangar access }\end{array}$ & & \\
\hline Monday & 2 flights & $\mathrm{X}$ & 7 \\
\hline \multirow[t]{2}{*}{ Tuesday } & $\begin{array}{l}\text { Soft down day (possibly one flight). Hangar } \\
\text { access: } 10 \text { a.m. to } 4 \text { p.m. }\end{array}$ & $\mathrm{X}$ & 3.5 \\
\hline & & Total & 35 \\
\hline
\end{tabular}

\subsection{Pilot Duty Day}

Pilots must adhere to the following FAA guidelines to ensure proper duty times under Federal Aviation Regulations Code 135:

- A flight day consists of the time between when they leave and return from their hotel room or domicile.

- If the flight day exceeds 10 hours, they must rest for at least 14 hours before they can resume operations. 


\subsection{Personnel Responsibilities}

\subsubsection{CARES Principal Investigator}

- Provides scientific recommendation for flight plan and go/no-go decision

- Reviews flight debrief information and makes scientific recommendations to flight plans or data collection strategy.

\subsubsection{Second-In-Command}

- Confers with the principal investigator on go/no-go decisions and flight plans

- Serves as principal investigator if the principal investigator cannot assume responsibilities.

\subsubsection{Aircraft Instrument Scientists}

- Attend pre-flight and post-flight briefings to report conditions of instruments and aircraft personnel

- Uploads data to IOP-Share FTP site.

\subsubsection{AAF Representative}

- Makes the final go/no-go call based on scientific recommendation and safety considerations

- Reports go/no-go decision to the pilot

- Communicates with aircraft team any concerns or suggestions from the science team

- Verifies flight-day summaries and wiki content (real-time data plots, QC plots, etc.)

- Tracks flight time available and keeps record on wiki site

- Supervises the timely availability of data and quicklook plots.

\subsubsection{CARES Forecaster}

- Distills information from PNNL model forecast, local CARB weather forecast, and CalNex weather forecast

- Provides planned agricultural burn location and time information from CARB meteorologist

- Provides satellite overpass information (Langley satellite prediction: http://www-air.larc.nasa.gov/tools/predict.htm)

- Provides same-day forecast, next-day forecast, and week-long outlook

- Posts brief weather statement on wiki page.

\subsection{Daily Ground Sites Operations}

\subsection{Radiosonde Launch Schedule}

The radiosondes will provide an important measure of lower atmosphere temperature and relative 
humidity as well as a snapshot of boundary-layer depth during the daytime sampling periods. Subject to adjustment as the campaign progresses, the following launch schedule will be followed at both T0 and T1:

- For days on which the G-1 has two flights, launches will occur at 0800, 1100, 1300, 1500, and 1800 PDT. (This places the middle launch at approximately solar noon.)

- For morning-only flight days, launches will occur at 0800, 1100, and 1400. Delaying the last sounding by an hour will sample the boundary layer closer to its maximum depth.

- For afternoon-only flight days, launches will occur at 1300, 1500, and 1800.

- For days with no flights, there will be a single launch at 1300.

Since the profiler also gives a measure of BL depth, we may dispense with at least the T1 sonde on scheduled no-flight days for the G-1. This will be especially important if we have very many one-flight days, since two of those will consume an extra sonde at each location compared to two-flight days if we follow the above schedule.

\subsection{Instrument Operation Schedule}

Some ground instruments will be operated continuously for 24 hours, 7 days a week, while others will be operated on a semi-continuous basis. Calibration schedule and procedure for each instrument will be performed according to the established protocols in the research community.

On the G-1 flight days, the CARES principal investigator will notify the ground site personnel of the approximate aircraft overpass times over each ground site so that the ground instruments can be calibrated (if necessary) ahead of time.

\subsection{Daily Data Evaluation and Dissemination}

Data evaluation will be performed on a daily basis after each flight. A representative from the aircraft team must upload flight data to the ARM IOP-Share archive within 24 hours after a flight from the aircraft team. At that time, quicklook plots will be auto-generated and posted on the CARES wiki site. It is the responsibility of the instrument mentor to perform QC checks on the data within one week of each flight to ensure quality data throughout the experiment and report any issues on the wiki site. The CARES steering committee will also examine the quicklook plots to help identify data issues and to ensure that data needs are met that will help fulfill the mission science objectives. Any problems with the data will be recorded in the comments section on the wiki site.

\subsection{Final CARES Data QC and Dissemination}

The final data set will be submitted to the ARM Data Archive by the instrument PIs within six months of the end of the experiment. AAF will create a public website where flight summaries, ground site daily logs, quicklooks, data quality reports, images, etc. will be posted for the general public. 


\subsection{References}

Bao, J-W, SA Michelson, POG Persson, IV Djalalova, and JM Wilczak. 2008. "Observed and WRFsimulated low-level winds in a high-ozone episode during the Central California Ozone Study." Journal of Applied Meteorology and Climatology 47: 2372-2394.

de Gouw, JA, et al. 2008. "Sources of particulate matter in the northeastern United States in summer: 1. Direct emissions and secondary formation of organic matter in urban plumes." Journal of Geophysical Research 113: D08301, doi:10.1029/2007JD009243.

Dillon, MB, MS Lamanna, GW Schade, AH Goldstein, and RC Cohen. 2002. "Chemical evolution of the Sacramento urban plume: Transport and oxidation." Journal of Geophysical Research 107: 4045, doi:10.1029/2001JD000969.

Jacobson, MZ. 2002. "Analysis of aerosol interactions with numerical techniques for solving coagulation, condensation, dissolution, and reversible chemistry among multiple size distributions." Journal of Geophysical Research 107: 4366, doi:10.1029/2001JD002044.

Kanakidou, M, et al. 2005. "Organic aerosol and global climate modelling: a review." Atmospheric Chemistry and Physics 5: 1053-1123.

Murphy, JG, DA Day, PA Cleary, PJ Wooldridge, DB Millet, AH Goldstein, and RC Cohen. 2007. "The weekend effect within and downwind of Sacramento - Part 1: Observations of ozone, nitrogen oxides, and VOC reactivity." Atmospheric Chemistry and Physics 7: 5327-5339.

Seinfeld, JH, and SN Pandis. 1998. Atmospheric Chemistry and Physics, From Air Pollution to Climate Change. John Wiley, Hoboken, New Jersey.

Wexler, AS, and JH Seinfeld. 1991. "Second-generation inorganic aerosol model." Atmospheric Environment 25A: 2731-2748.

Zaveri, RA, RC Easter, JD Fast, and LK Peters. 2008. "Model for Simulating Aerosol Interactions and Chemistry (MOSAIC).” Journal of Geophysical Research 113: D13204, doi:10.1029/2007JD008782.

Zhang, Q, et al. 2007. "Ubiquity and dominance of oxygenated species in organic aerosols in anthropogenically-influenced northern hemisphere mid-latitudes." Geophysical Research Letters 34: L13801.

Zhang, Y, B Pun, K Vijayaraghavan, S-Y Wu, C Seigneur, SN Pandis, MZ Jacobson, A Nenes, and JH Seinfeld. 2004. "Development and application of the Model of Aerosol Dynamics, Reaction, Ionization, and Dissolution (MADRID)." Journal of Geophysical Research 109: D01202, doi:10.1029/2003JD003501. 


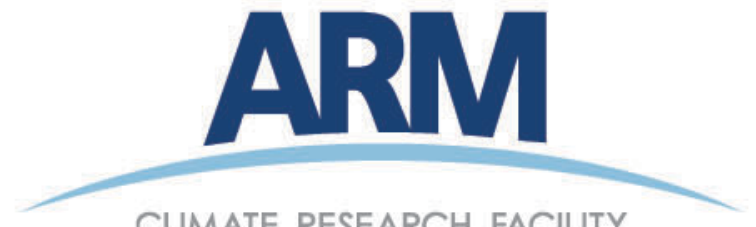

CLIMATE RESEARCH FACILITY

www.arm.gov

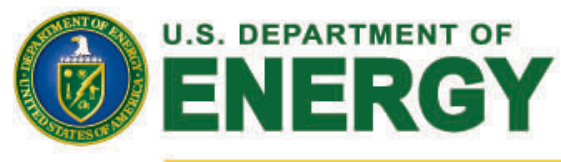

Office of Science 